\title{
Improved process and results of civic education (Pkn) with cooperative model course review horay in elementary school
}

\section{Reinita}

Universitas Negeri Padang, Padang - Indonesia, (reinita_reinita@yahoo.com)

\begin{abstract}
The problem of this study is low process and result of students learning in Civic Education (PKn). The purpose of this study is to improve the process and the result of students learning in Civic Education (PKn). The type of research used is classroom action research with qualitative and quantitative approach. The subjects of this study were teachers and 27 students in grade 4th. This research shows that there was an increase of lesson plan from cycle I that is average $76,78 \%$ to $92,85 \%$ in cycle II. Implementation of learning on teacher aspect and student aspect increased from average $77,25 \%$ in cycle I to be $93.18 \%$ in cycle II. And the increase of students learning outcomes increased from the average of 74.45 increased to average of 90.16 in cycle II. It can be concluded that by using classroom action research with qualitative and quantitative approach (Course Review Horay Model) can improve process and result of students learning.
\end{abstract}

Keywords: learning outcomes, learning civic education (PKn), classroom action research, course review horay.

\section{Introduction}

The learning process is a process that contains a series of activities of teachers and students on the basis of reciprocal relationships that take place in educational situations to achieve certain goals. Civic education (PKn) subjects focus on the affective domain.

According to Depdiknas (2006: 271) subjects Civic Education (PKn) aims to students are able to, 1) Think critically, rationally, and creatively in responding to the issue of citizenship. 2) Participate actively and responsibly and act intelligently in the activities of society, nation, and state and anticorruption. 3) Growing positively and democratically to establish themselves based on the characters of Indonesian society in order to live together with other nations. 4) Interact with other nations in the world arena directly or indirectly by utilizing information and communication technology.

In comprehend the understanding and purpose of learning civic education (PKn), teachers should be able to create an atmosphere of learning process become interesting and meaningful for students. Teachers should be able to motivate students to identify the latest issues that are happening in the society, so that students can express their opinions by providing logical and rational reasons. 
Teachers should guide students to determine the values that are included in the case and direct the students to be able to apply good value in everyday life.

Based on the results of interviews, observations and documentary studies that the researchers did with the principal and self-reflection of the teachers of grade IVA SD Negeri 10 Sapiran Kota Bukittinggi on March 7 and March 14, 2017 were known that the lesson of civic education(PKn) runs less than optimal. This can be seen from two aspects, namely teacher aspect and student aspect. From the aspect of teachers, the cause is less variation of the model used by the teacher so that the students are easily bored in the learning process, the teacher only focuses on the cognitive domain only and less attention to the affective field, the teacher used to give practice questions that available in the worksheet(LKS), the concept given by the teacher is limited in the existing package of books and rarely associated with daily life, teachers are less motivating students to actively analyze the latest cases in the society, teachers are less guiding students in determining opinions, less to develop openness, teachers are less to guide students in defending their opinions with logical and rational reasons that can improve students' verbal skills.

To overcome these problems, teachers should be able to create a learning atmosphere that attracts attention and stimulates students to be actively involved and interested in civic education(PKn) learning activities. One that can be done is the ability to use learning models in the learning process. One of the models that can be used in this civic education(PKn) learning is model course review horay. The course review horay model can train students to be sensitive to current social problems, analyze existing social problems, take positions on the issue, and maintain attitudes with relevant and valid arguments so that students can participate in redefining the values social.

According to Taufina and Muhammadi (2011: 158) "Course Review Horay is a learning by comprehension test using a box or a card filled with numbers to write down the answer, the first gets a direct sign right shouted hurray.

According to Shoimin (2014: 55) the advantages obtained by using the Course Review Horay model in learning are: 1) Interesting to encourage students to be involved in it, 2) not monotonous because it is interspersed with little entertainment so that the atmosphere is not stressful, 3) the students are more excited, 4 ) train cooperation. So that, researchers looking for solutions and interested in conducting Classroom Action Research (PTK) to improve the process and student learning outcomes on learning civic education(PKn) model Course Review Horay in grade 4th (classA)Public Elementary School number 10 Sapiran Bukittinggi City. The purpose of this study is to describe the improvement of learning process and student learning outcomes on civic education(PKn) learning with Course Review Horay model in grade 4th (class-A)Elementary School

\section{Method}

The approach used in this research is qualitative and quantitative approach. Bogdan and Bigland in Sugiono (2006: 14) states that "a qualitative approach is used for a research procedure that produces data in the form of written / oral words, as well as observed behavior of people or sources of information".

The type of research used in this research is Classroom Action Research (PTK). According Kemmis and Taggart (1992: 5) "Action research is a form of reflective research by performing certain actions with the aim of improving or increasing the process of learning and performance as a teacher".

The research was conducted in the second half of January-June 2016/2017. This study was conducted two cycles, each cycle held two meetings. The type of data in this research is observation result, unstructured interview, field note, test result from every corrective action on process and 
result of learning of civic education(PKn). The data relates to the planning, implementation, and assessment of teacher aspects and student aspects.

Data collection techniques in this study were collected by observation. Observation was done by the observer during the learning takes place in every cycle. The observed aspect is the civic education( $\mathrm{PKn})$ learning activities which include planning, implementation and assessment. Observation activities are done by direct observation through sight and hearing of all phenomena that appear in each cycle by using a prepared observation format.

The data of this study were analyzed by using qualitative data analysis, such as offered by Miles and Huberman (1992: 18-20) ie, data analysis started by reviewing data since data collection until all data collected. Quantitative data analysis in this study was conducted on data that has been reduced, both data planning, implementation, and data assessment of learning civic education(PKn) with the formula:

$$
\begin{aligned}
& \mathrm{p}=\underline{\mathrm{F}} \times 100 \% \text { ( Sugiono 1997). } \\
& \mathrm{N} \\
& \text { Description: } \mathrm{F}=\text { scores obtained } \\
& \mathrm{P}=\text { percentage of scores } \\
& \mathrm{N}=\text { the maximum number of scores obtained }
\end{aligned}
$$

\section{Results and Discussion}

\section{Cycle I}

Research cycle I held two meetings, ie on September 4, 2017 and September 11, 2017 at SD 10 Sapiran Bukittinggi City. Research carried out in accordance with the groove made, namely: (1) Planning, (2) implementation of action, (3) observation of learning outcomes, and (4) reflection. It can be described as follows:

\section{Planning}

Application of Course Review Horay model in civic education(PKn) learning is prepared and realized in the form of lesson plan (RPP), lesson plan (RPP) is compiled by researchers in collaboration. Before lesson plan (RPP) prepared by researcher and classroom teacher, first analyze the basic competence (KD) that was developed based on KTSP subjects civic education(PKn)grade 4 th semester II. The decree (SK) to be achieved in the implementation of this research is "Demonstrate attitudes toward globalization in its environment", while the KD taken is "Determining attitudes toward the influence of globalization that occurred in the environment", the researcher takes the material of globalization influence in the field of communication in cycle I meeting I. The expected indicators achieved is consist of cognitive and affective aspects. Indicators of cognitive aspects include: (a) Identifying social problems about the impact of globalization in the field of communications that occur in society. Indicators of the affective aspect are: (b) Determine the attitude of accepting and rejecting the influence of globalization in the field of communication that occurs in society, (c) Stating the opinion of the attitude of accepting and rejecting the effects of globalization that occur in the community environment for logical and rational reasons.

Before the implementation of the learning process begins, first the researchers prepare lesson plan (RPP), learning media, evaluation sheets to be used in learning. In addition, the researcher also prepares the observation sheet to observe the affective aspects and the observation sheet to observe the course of the learning process to be observed by the observer. The learning process is designed in 
accordance with the Course Horay Review steps and in the planning activities are composed of initial, core and end activities.

\section{Implementation}

The first cycle of meeting was held on Monday, September 4, 2017, and the second meeting was held on September 11, 2017. The implementation of the action begins with the opening of the greeting and asks the students to tidy up the class, pay attention to the cleanliness of the classroom, then ask the class leader to lead the prayer and pray together, check the attendance list of students and then the researcher conveys the material and goals to be learned. After that the researcher proceeded to the core activities.

Step 1, the teacher conveys the learning objectives in accordance with the basic competence (KD) to be studied, the teacher conveys the subjects and asks questions to the students.

Step 2, the teacher publishes and displays the image media about the communication tool and conducts question and answer with the students about the image media. Furthermore, the teacher read a case about the effect of mobile phone for students, and students give response to the case read by the teacher.

Step 3, the teacher divides the students into 5 groups, each group of 5-6 students. The division of groups is divided heterogeneously by sex. The teacher asks the students to sit in their group and appoint the group leader as well as giving the name the group.

Step 4, the teacher gives the tool ie scissors and rollers, the teacher asks each group to make 5 pieces of paper from the size of the paper $(10 \times 10 \mathrm{~cm})$ and give the card number, then the teacher will start to read the question.

Step 5, the teacher reads randomly and the students discuss with the group, so the teacher asks the students to write their answers on the numbered cards according to the number of questions read by the teacher.

Step 6, teachers and students check the questions from the answers that have been read, then the teacher asks students to deliver the answers she/he wrote. Furthermore, teacher and students discuss the most appropriate answer.

Step 7, teachers and students conclude the correct answers from teacher questions. The teacher checks the answers of each group, for the group with the correct answer the teacher asks the students to tick the checklist $(\sqrt{ })$ and immediately shouts 'hurray !!!'. Teacher is back to do steps 1-7 with different number of questions.

Step 8, the teacher asks the students to count the number of times they shouts huray and counts the checks on the card and the teacher asks the students to report how many checks they get. Furthermore, the teacher asked the students to calculate the score of each group that many shouted huray and write the score at the end of the answer card then ended with the teacher asking which the difficult questions.

Step 9, the teacher announces the score of each group, the teacher asks the students to write the score on the group's name. Furthermore, the teacher awarded the certificate to the group who got the highest score.

Activities which are undertaken at the end of the lesson are teacher gives the opportunity to comment on the learning that lasts from the beginning to the end of the lesson. Then the teacher gives an evaluation sheet about the decisions to each student and the student works to complete the 
evaluation question that the teacher distributes. After that the teacher guides the students to close the learning activities by reading prayers and greetings.

\section{Observation}

The result of observation in cycle I was done on lesson plan (RPP), teacher aspect, student aspect, and student learning outcomes both at meeting I and meeting II. The following results of observations on these four aspects in cycle I, lesson plan (RPP) obtained a value of $71.42 \%$ at the meeting I and $82.14 \%$ at the second meeting, with the average acquisition of lesson plan (RPP) cycle I 76.78. Observation of teacher aspect got $72,7 \%$ value at meeting I and $81,81 \%$ at meeting II, with average aspect of teacher of cycle I 77,25 . Student aspect observation got $72,7 \%$ in cycle I and $81,81 \%$ in cycle II, with mean of student aspect of cycle I 77,25. And the observation of student learning outcomes on the cognitive aspect obtained a value with an average of 69.83 in cycles I and 76.17 at the second meeting, with an average cognitive value in cycle I 73. Observation of student learning outcomes on the affective aspects of scores 72.08 at first meeting and 75 at the second meeting.

\section{Reflection}

Based on observations and tests that have been done, it can be reflected that the planning, implementation, observation, and student learning outcomes by using the model course horay review has not been implemented with the maximum. In addition, student learning outcomes also have not reached the expected category of success. Thus the research will continue on cycle II. Hopefully in cycle II can achieve what is expected.

\section{Cycle II}

In this second cycle, the research is only conducted for a meeting. The second cycle was conducted on September 25, 2017. The research in cycle II is still the same as the research in cycle I, starting from: (1) planning, (2) implementation, (3) observation, and (4) reflection. It can be described as follows:

\section{Planning}

Learning in cycle II is implemented so that students can determine attitudes toward the globalization that occurs in the environment by using the model course horay review. The indicators on cognitive aspects are: (a) Identify the effect of globalization on the culture of Indonesian society. Indicators of affective aspects are: (b) determining how to introduce Indonesian nation culture to the world, (c) determining attitude in facing globalization influence from various environments.

\section{Implementation}

Cycle II begins on September 25, 2017. The action begins with the opening greetings, asking students to tidy up the class, pay attention to the cleanliness of the classroom, ask the class leader to pray and pray together and check the attendance list. Furthermore, researcher conveys the material and objectives to be studied. After that the researcher proceeded to the core activities.

Step 1, the teacher conveys the learning objectives in accordance with the basic competence (KD) to be studied, the teacher conveys the subjects and asks questions with the students.

Step 2, the teacher publishes and displays the image media about the communication tool and conducts question and answer with the students about the image media. Then, the teacher reads a case about the effect of mobile phones for students, and students respond to cases read by teachers.

Step 3, the teacher divides the students into 5 groups, each group of 5-6 students. The division of groups is divided heterogeneously by sex. The teacher asks the students to sit in their group and appoint the group leader as well as name the group.

Step 4, the teacher gives the tool that is scissors and rollers, the teacher asks each group to make 5 pieces of paper with size $(10 \times 10 \mathrm{~cm})$ and give the card number, and the teacher starts to read the question. 
Step 5, the teacher reads questions randomly and the students discuss with the group, so the teacher asks the students to write their answers on the numbered cards according to the number of questions read by the teacher.

Step 6, teacher and students check the questions from the answers that have been read, then the teacher asks students to deliver the answers she/ he wrote. Then teachers and students discuss the most appropriate answer.

Step 7, teacher and students conclude the correct answers from teacher questions. The teacher checks the answers of each group, for the group with the correct answer the teacher asks the students to tick the checklist $(\sqrt{ })$ and immediately shouts 'hurray !!!'. Teacher is backdoing the steps 1-7 with different number of questions.

Step 8, the teacher asks the students to count the number of times the student shouts huray and counts the checks on the card and the teacher asks the students to report how many checks they get. Furthermore, the teacher asked the students to calculate the score of each group that many shouted huray and write the score at the end of the answer card then ended with the teacher asking which difficult questions.

Step 9, the teacher announces the score of each group, the teacher asks the students to write the score on group's name. The teacher rewards the certificate to the group with the highest score.

Activities are undertaken at the end of the lesson are teacher giving the opportunity to comment on the learning that lasts from the beginning to the end of the lesson. Then the teacher gives an evaluation sheet about the decisions to each student and the student works to complete the evaluation question that the teacher distributes. After that the teacher guides the students to close the learning activities by reading prayers and greetings.

\section{Observation}

This is the same with cycle I, cycle II is also done observations about lesson plan (RPP), aspects of teachers, student aspects, and student learning outcomes. The following is the result of observation from four aspects: (a) lesson plan (RPP) observation in cycle II get value $92,85 \%$, observation of teacher aspect in cycle II get value 93,18\%, observation of student aspect in cycle II get value $93,18 \%$, and student learning outcomes in cycle II on the cognitive aspect obtained an average value of 90.33 and on affective aspects obtained an average value of 90 .

\section{Reflection}

Based on the results of observations and test results that have been implemented, it can be reflected that the planning, implementation, and learning outcomes of students using the model review course horay has been done well and students learning outcomes also have reached the expected criteria. Thus, the research is sufficient until here and not continued again in the next cycle.

\section{Cycle I \\ Planning}

In the first lesson plan (RPP) of cycle I, researcher has not been optimal in making it, it is evident from the results of observation lesson plan (RPP) of 28 maximum scores only get 20 scores at the meeting I and 23 scores at the second meeting with the average percentage obtained 76.78. Means that in the lesson plan (RPP) cycle I researcher has not been optimal in making the lesson plan (RPP), so that the criteria obtained not in accordance with the expected. Therefore, the research will proceed to cycle II.

\section{Implementation}

Implementation of learning in cycle I was held in 2 meetings. Based on the discussion of the researcher with the class teacher, the implementation of civic education( $\mathrm{PKn})$ learning using the 
course review horay model found the following things: (1) In the initial activity the teacher did not give an aperception before the learning started as stated in the lesson plan, (2) the teacher has not given explanation about the material (3) the teacher does not display the media of the picture, (4) the teacher does not read the case of the effect of mobile phone for students who will bridge the students in the discussion of the material, and (5) the teacher does not instruct the students to give the checklist on the right answer, (6) the teacher has not asked the difficult questions for the students, and (7) the teacher has not motivated the group that has not got the most checklist.

Based on the observation sheet, the result of the observation data of teacher and student activity activity on the first cycle of meeting 1 obtained the percentage of score $72,7 \%$ with sufficient qualification on teacher aspect, and $72,7 \%$ with sufficient qualification in student activity. Furthermore in the first cycle of meeting 2 obtained the percentage of $81.81 \%$ with good qualification on the aspect of teachers, and $81.81 \%$ with good qualification on the aspects of students. Therefore, it obtained the success criteria with the percentage of the average score of $77.25 \%$ with qualifications both on teacher activity and student activity.

The shortcomings in the implementation of cycle I of meeting I and II should be improved in the next cycle.

\section{Learning outcomes}

Assessment of learning outcomes is done on the cognitive domain and affective sphere. Based on the observational data analysis of student learning outcomes in the first cycle of meeting 1 of the cognitive aspect obtained the average of cognitive learning outcomes is 69.83. Assessment of affective aspects gained an average of 72.08. Then obtained the average of student learning outcomes in the cycle I meeting I is 70.95. And for the first cycle of meeting 2 obtained the average of cognitive learning outcomes that is 76.16 , on the affective aspect obtained an average of 79.74 . Then obtained average - average student learning outcomes during the first cycle of meeting II is 77.95

Based on the above assessment, the average learning outcomes of students in the first cycle is 70.95 and 77.95 , with an average of 74.45, this indicates that student learning outcomes have not been achieved as expected, to cycle II.

\section{Cycle II}

Planning

In the second cycle of lesson plan (RPP) more refined, and the results of the lesson plan (RPP) assessment in cycle II is satisfactory because of an increase compared to the lesson plan (RPP) cycle I. This increase is due to improvements made in cycle II and in this second cycle of lesson plan (RPP) has been designed as possible to be able to achieve maximum learning outcomes. And the result of lesson plan (RPP) assessment based on observation sheet get the percentage of value $92,85 \%$ with very good qualification. This proves shows that the increase, means improvement efforts made in cycle II has been successful in accordance with what is expected.

\section{Implementation}

Based on the results of the discussion of researchers with classroom teachers in cycle II, the implementation of learning has been done well. This can be seen from the results of the observer's assessment of teacher activity and students in cycle II, that is obtained by the percentage value of 93.18\% with excellent qualifications on the aspect of teachers, and $93.18 \%$ with excellent qualifications on the aspects of students. Based on the acquisition of the score, the activity of teachers and students has increased, and is in accordance with the expected.

\section{Learning Outcomes}


On the improvement of learning cycle II has yielded results, the results obtained have been in accordance with the expected. This is seen in the data analysis of student observations in terms of cognitive and affective aspects, the cycle II cognitive aspects obtained an average of 90.33 and on affective aspects to obtain an average of 90 . Based on the assessment, the average cognitive and affective learning outcomes ie 90.16. Based on the results obtained, the learning outcomes in cycle II is in accordance with what is expected. Therefore, it can be concluded that student learning outcomes on learningcivic education(PKn) with model course review horay has been achieved in accordance with the expected criteria, this means research stops until here and not resumed in the next cycle.

\section{Conclusions}

Based on the data of research and discussion about the effort to improve the learning of Civics with the model of course review horay it can be concluded that the implementation plan of learning Civics in grade IV SD has been done well, average of $76.78 \%$ increased to an average of $92.85 \%$ in cycle II. Furthermore, the implementation of learning is also increased, this can be seen from the improvement of aspects of teachers and aspects of students with an average of $27.24 \%$ in the first cycle increased to $93.18 \%$ in cycle II. And on the learning outcomes of the students also increased, it can also be seen from the average value of 74.45 in the first cycle increased to 90.16 in cycle II.

Based on the above conclusions, it can be suggested the following: in the learning phase of a teacher should really pay attention to the important components in the lesson plan (RPP) based on KTSP 2006, a teacher should really be able to master and condition the class so that learning can take place well, and a teacher must really be able to pay attention to student learning outcomes.

\section{References}

Depdiknas. (2006). Kurikulum Tingkat Satuan Pendidikan. Jakarta: Depdiknas.

Miles. M. B \& Huberman, A.M. Analisis data kualitatif. Jakarta: Universitas Indonesia.

Shoimin, Aris. (2014). 68 Model Pembelajaran Inovatif dan Kurikulum 2013. Yogyakarta: Ar-Ruzz Media.

Stephen Kemmis \& Robin McTaggart.(1988). The Action Research Plamner. $3^{\text {rd }}$ ed. Victoria: Deakin University.

Sugiyono.(1997). Metode Penelitian Kuantitatif Kualitatif dan RND. Bandung: alfabeta

Taufik, Taufina \& Muhammadi. (2011). Mozaik Pembelajaran Inovatif. Padang:Sukabina Pres. 